\title{
Training Needs Assessment of Women Farmers on Livestock Production Management in Bundi District of Rajasthan, India
}

\author{
B.L. Dhaka*, R.K. Bairwa, N.L. Meena, G.S. Meena, K. Chayal and B.L. Nagar \\ Krishi Vigyan Kendra, Bundi - 323001 Rajasthan, India \\ *Corresponding author
}

\author{
A B S T R A C T
}

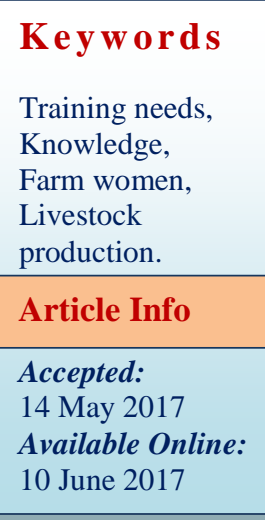

Keywords

Training needs,

Knowledge,

Farm women,

Livestock

production.

Farm women play an important role in managing different kinds of livestock production operations. However, the degree of their participation in various livestock production activities is governed by the socio-cultural and economic factors. Women in some settings are faced with discrimination and are less accessible to extension services and appropriate technology. There is poor awareness regarding ways of improving livestock productivity to improve livelihoods. Further, lack of training is also identified as factor militating against women farmers' efficiency and effectiveness. This paper identifies training needs of farm women in livestock production. The study was conducted in Bundi district of Rajasthan. A multi-stage sampling design was used to select the sample households. A sample of 250 farm women was selected based on random sampling procedure. The selected respondents were interviewed personally with the help of a well-structured and pre-tested interview schedule. Study revealed that women perform virtually all livestock production related operations, although they are less involved in marketing of livestock products; construction of livestock houses. The level of knowledge of women farmers was low in breeding and reproduction management, health management, livestock waste management. Majority of respondent farm women required intensive training on breeding and reproduction management, health management practices, livestock waste management, credit source and credit procurement procedure, insurance, disaster relief and risk management.

\section{Introduction}

Livestock plays an important role in the economy of India in general and sustainable livelihood of poor people of rain-fed agroecosystem in particular, because of inherent risk involved in the crop farming due to uncertainty of rainfall and occurrence of recurrent droughts (Misra, 2005). In India, income from livestock production accounts for $15-40 \%$ of total farm household earnings (World Bank, 1999). Apart from the monetary benefits provided by milch animals, the role of small ruminants like goats and sheep is very important, as they serve as a lifeline during drought years by providing income and sustenance. Farm women play an important role in managing different kinds of livestock production operations. The role of women in livestock production varies amongst underprivileged groups and between regions. In tribal communities, women play a major role in livestock production as well as in the sale of produce, while pastoral women are generally involved in looking after the new born and sick animals. Amongst most of 
the other backward communities, women have a greater role with small animals and backyard poultry, while men manage large animals. However, the degree of participation of women in various farming activities is governed by the socio-cultural and economic factors. Women in some settings are faced with discrimination and are less accessible to land, credit, agricultural inputs, agricultural extension services and appropriate technology. There is poor awareness regarding ways of improving livestock productivity to improve livelihoods. In addition to the above stated problems, CTA (1993) identified lack of training as part of the factors militating against women farmers' efficiency and effectiveness. The measure suggested for removing the obstacle is to train rural women to improve their ability to do their vocation more effectively and efficiently. So that, training and dissemination of information to farm women will be a critical input for the modernizing of farm production and home management in rural areas (World Bank, 1992). Keeping the role of farm women in mind, there is a need for training farm women regarding to necessary technologies, so that they can perform those activities with more competences. Meanwhile, a pre-requisite to reach this, is to access information needs and information seeking behavior of the farm women. Improving the knowledge and skills of women about how improving the productivity of livestock would bring in a short time quantitative and qualitative improvements in the livestock production.

\section{Materials and Methods}

The study was conducted in Bundi district of Rajasthan. A multi-stage sampling design was used to select the sample households. In first stage, Hindoli block of the Bundi district was selected purposively. In second stage, four villages were purposively selected to ensure good representation of the district. Finally in third stage, a total of 250 women, representing households, were selected from selected villages in proportion to the population in each selected villages. The selected respondent farm women were interviewed personally with the help of a well structured and pre-tested interview schedule.

In order to ascertain the training need, an exhaustive list of possible needs was prepared through meticulous review of literature, consultation with experts and extension workers. Responses of respondents were quantified by assigning the score of 3,2,1,0 for "most needed", "needed", "somewhat needed" and "not need" respectively. The data thus collected were tabulated and statistically analyzed to interpret the results. The overall training need of farmers have been measured in terms of training need quotient (TNQ). On the basis of TNQ, the respondents were categorized into low, moderate and high training need intensity on the basis of equal intervals.

The knowledge was operationalised as the information possessed by the farm women about various aspects of good management practices for sustainable livestock production with adequate understanding. The knowledge of individual women was measured through a schedule prepared for the study purpose. The response of women was obtained on three point continuum i.e. fully correct, partial correct and incorrect, and scores of 2, 1, and 0 were assigned, respectively. Item wise scores were assigned and thus total score for each aspect of livestock production was worked out. On the basis of mean knowledge score, the respondents were categorized into low, medium and high knowledge on the basis of equal intervals.

To study communication sources utilized by respondent farm women for seeking 
information regarding to livestock production, respondents were given a list of communication sources and asked to select these they use often. Data thus collected were tabulated and analyzed using appropriate quantitative approaches.

\section{Results and Discussion}

\section{Socio economic characteristics of respondents}

A profile of socio economic characteristics of respondent farm women were analysed and presented in table 1 . The table indicated that majority $(51.6 \%)$ of the respondents belonged to middle age group followed by old age $(27.2 \%)$ and young age $(21.2 \%)$ group. The frequency distribution was highly skewed towards the older respondents. This implies that the younger ones were less involved in livestock production. While looking at the educational status of respondent, results revealed that majority $(70.8 \%)$ of respondents were illiterate followed by functionally literate (up to middle class) (24.4 $\%)$, high school (4.8\%) whereas nobody was educated more than high school level. The low percentage of those with formal education may be adversely influence adoption of innovations in livestock production. Results on land holding show that nearly 80.00 per cent of respondents were marginal (33.6\%) to small (50.4\%) farmers. Further, it was also observed that majority of respondents were resource poor (54.4\%).

The study also showed that the percentage of respondents having non descriptive animal was very high (66.8) whereas only 12.8 per cent of respondent had cross breed animals. Consequently the milk production of majority $(55.2 \%)$ of the respondents fell under low category whereas majority $(34.4 \%)$ of the respondents belonged to medium milk production category.
Out of total 250 respondents interviewed, 58.8.00 per cent had a low exposure to the mass media followed by 30.0 per cent and 11.2 per cent had medium and high exposure to the mass media, respectively. Due to their low exposure to mass media, the respondents were unaware of all the developments in the field and were not able to cope up with the changes and are not realizing much profits resulting in lower annual income.

\section{Role performed by farm women}

Data in table 2 show the identified livestock farming operations in the study areas. The farm women performed all the operations. The table clearly indicates that majority of women farmers were involved in feeding of animals $(100 \%)$, care and feeding of new born $(100 \%)$, disposal of livestock waste (100\%), milking and processing (100\%). However, they are less involved in construction of livestock houses $(45.2 \%)$, selection of livestock (54.4\%), marketing of livestock (49.2\%), treatment of sick animal (69.2\%), control of external and internal parasites $(85.2 \%)$, animal breeding $(66.8 \%)$, milk marketing (51.6). These operations were mainly performed by men, but all the same, the involvement of women in them is substantial. It is an indication of increased participation of women in livestock production activities. Similar observations were also reported by Farinde and Ajayi (2005).

\section{Knowledge level of farm women}

Livestock management was always perceived as the traditional responsibility of women. Here attempt has been made to measure the knowledge level of farm women on livestock production operation and results presented in table 3. 
Table.1 Socio economic profile of respondent's farmers

\begin{tabular}{|l|l|c|c|}
\hline Variables & Category & Frequency & Percentage \\
\hline Age (in years) & Young $(<30)$ & 53 & 21.2 \\
\hline & Middle (31-50) & 129 & 51.6 \\
\hline & Old (>50) & 68 & 27.2 \\
\hline Education & Illiterate & 177 & 70.8 \\
\hline & $\begin{array}{l}\text { Functional literate } \\
\text { up to middle class) }\end{array}$ & 61 & 24.4 \\
\hline & High school & 12 & 4.8 \\
\hline & Graduate and above & 0 & 0 \\
\hline Holdings & Marginal & 84 & 33.6 \\
\hline & Small & 126 & 50.4 \\
\hline & Medium & 27 & 10.8 \\
\hline & Large & 13 & 5.2 \\
\hline Resourcefulness & Rich & 47 & 18.8 \\
\hline & Medium & 67 & 26.8 \\
\hline & Poor & 136 & 54.4 \\
\hline Herd composition & Non descriptive & 167 & 66.8 \\
\hline & Improved breed & 51 & 20.4 \\
\hline & Both & 32 & 12.8 \\
\hline Milk production & Low & 138 & 55.2 \\
\hline & Medium & 86 & 34.4 \\
\hline & High & 26 & 10.4 \\
\hline Mass media exposure & Low & 147 & 58.8 \\
\hline & Medium & 75 & 30 \\
\hline & High & 28 & 11.2 \\
\hline
\end{tabular}

Table.2 Distribution of women farmers by livestock production operation performed

\begin{tabular}{|l|c|c|}
\hline Livestock Operations & Frequency & Per cent \\
\hline Selection of livestock & 136 & 54.4 \\
\hline Marketing of livestock & 123 & 49.2 \\
\hline Construction of livestock houses & 113 & 45.2 \\
\hline Feeding of Animals & 250 & 100 \\
\hline Disposal of livestock waste & 250 & 100 \\
\hline Animal breeding & 167 & 66.8 \\
\hline Treatment of sick animal & 173 & 69.2 \\
\hline $\begin{array}{l}\text { Control of external and internal } \\
\text { parasites }\end{array}$ & 213 & 85.2 \\
\hline Care and feeding of new born & 250 & 100 \\
\hline Milking and processing & 250 & 100 \\
\hline Milk marketing & 129 & 51.6 \\
\hline
\end{tabular}


Table.3 Distribution of respondent on the basis of their knowledge level

\begin{tabular}{|l|l|l|l|l|l|l|}
\hline \multirow{2}{*}{ Aspects } & \multicolumn{6}{|c|}{ Knowledge level } \\
\cline { 2 - 7 } & Low & Medium & High \\
\cline { 2 - 7 } & Frequency & Per cent & Frequency & Per cent & Frequency & Per cent \\
\hline $\begin{array}{l}\text { Breeding and reproduction } \\
\text { management }\end{array}$ & 123 & 49.2 & 88 & 35.2 & 39 & 15.6 \\
\hline Housing management & 73 & 29.2 & 127 & 50.8 & 50 & 20 \\
\hline $\begin{array}{l}\text { Health management } \\
\text { Practices }\end{array}$ & 161 & 64.4 & 62 & 24.8 & 27 & 10.8 \\
\hline Nutrition management waste & 47 & 18.8 & 144 & 57.6 & 59 & 23.6 \\
\hline $\begin{array}{l}\text { Livestock } \\
\text { management }\end{array}$ & 50.8 & 100 & 40 & 23 & 9.2 \\
\hline $\begin{array}{l}\text { Clean milk production and } \\
\text { marketing }\end{array}$ & 53 & 21.2 & 157 & 62.8 & 40 & 16 \\
\hline
\end{tabular}

Table.4 Distribution of respondent on the basis of technical training need

\begin{tabular}{|l|c|c|c|c|c|c|}
\multicolumn{1}{|c|}{ Training need intensity } \\
\hline
\end{tabular}

Table.5 Distribution of respondent on the basis of marketing training need

\begin{tabular}{|l|c|c|c|c|c|c|}
\multicolumn{1}{c|}{ (n=250) } \\
\cline { 2 - 7 } & \multicolumn{2}{|c|}{ Low } & \multicolumn{2}{c|}{ Moderate } & \multicolumn{2}{c|}{ High } \\
\cline { 2 - 7 } & Frequency & Per cent & Frequency & Per cent & Frequency & Per cent \\
\hline $\begin{array}{l}\text { Current \& future marketing } \\
\text { prices }\end{array}$ & 178 & 71.20 & 61 & 24.40 & 11 & 4.40 \\
\hline $\begin{array}{l}\text { Market Location and } \\
\text { Selling Beyond Farm Gate }\end{array}$ & 171 & 68.40 & 64 & 25.60 & 15 & 6.00 \\
\hline $\begin{array}{l}\text { Credit Sources and } \\
\text { Procurement Procedure }\end{array}$ & 96 & 38.40 & 132 & 52.80 & 22 & 8.80 \\
\hline Production timing & 193 & 77.20 & 57 & 22.80 & 0 & 0.00 \\
\hline
\end{tabular}


Table.6 Distribution of respondent on the basis of Social information needs

\begin{tabular}{|l|c|c|c|c|c|c|}
\multicolumn{1}{|c|}{ Low } & \multicolumn{7}{c|}{ Degree of Need } \\
\cline { 2 - 7 } & \multicolumn{2}{|c|}{ Low } & \multicolumn{2}{c|}{ Moderate } & \multicolumn{2}{c|}{ High } \\
\cline { 2 - 7 } & Frequency & Per cent & Frequency & Per cent & Frequency & Per cent \\
\hline Insurance & 36 & 14.40 & 77 & 30.80 & 137 & 54.80 \\
\hline Specialized commodities & 66 & 26.40 & 123 & 49.20 & 61 & 24.40 \\
\hline Disaster relief & 43 & 17.20 & 64 & 25.60 & 143 & 57.20 \\
\hline Community based practices & 72 & 28.80 & 97 & 38.80 & 81 & 32.40 \\
\hline Risk management & 46 & 18.40 & 68 & 27.20 & 136 & 54.40 \\
\hline
\end{tabular}

Table.7 Distribution of respondents on the basis of information sources utilization pattern

\begin{tabular}{|l|c|c|}
\hline Sources & Frequencies & \% \\
\hline Husband, Friends and neighbors & 213 & 85.20 \\
\hline Personal experience & 167 & 66.80 \\
\hline Opinions of leaders & 117 & 46.80 \\
\hline Educated people & 103 & 41.20 \\
\hline Extension personnel & 87 & 34.80 \\
\hline Extension literature & 47 & 18.80 \\
\hline Mass media & 56 & 22.40 \\
\hline
\end{tabular}

Data in table 3 show that majority of women farmers had low knowledge level in breeding and reproduction management $(49.2 \%)$, health management $(64.4 \%)$, livestock waste management $(50.8 \%)$. Further, it was observed that majority of the respondent had medium knowledge level in housing management $(50.8 \%)$, nutrition management $(57.6 \%)$ and clean milk production and marketing $(62.8 \%)$. Similar results were also reported by Farinde and Ajayi (2005). Thus, it was suggested that extension services to farmer women needs to be improved so that they can access the relevant information on the good management practice of sustainable livestock production.

\section{Training needs}

The training needs of respondent farmer women about various aspects of good management practices for sustainable livestock production were identified and presented in table 4 to 6 .

Data presented in table 4 indicate overall training need of respondent farm women on various technical aspects of livestock production.

It is obvious from the table that majority of respondent farm women required intensive training on health management practices $(62.40 \%)$, nutrition management $(58.80 \%)$ and breeding and reproduction management $(46.40 \%)$ aspect of livestock production. Further, livestock waste management $(68.40$ $\%)$, housing management $(52.40 \%)$ were the aspects where respondent women required training to moderate intensity. However, 66.80 per cent farm women indicated very low intensity of training need about clean 
milk production and marketing. Rezvanfar et al., (2007) was also reported similar results.

The table 5 exhibits that marketing information was not highly needed by a majority of the respondents. It was observed that credit source and credit procurement procedure were two aspects that respondent needed more training. These findings suggest that respondent do not perceive marketing of their produce as a serious problem. Similar results were also reported by Dhaka et al., (2003).

It is observed from table 6 that training related to disaster relief $(57.20 \%)$ followed by insurance $(54.80 \%)$ and risk management $(54.40 \%)$ were highly needed by most of the respondents. Thus, these findings reveal the significance of insurance, disaster relief and risk management in arid and semi-arid regions where drought is a frequently occurring phenomenon. Again, specialized commodities were the other area of interest in which respondents $(49.20 \%)$ needed training to moderate intensity. These findings were in consonance with the findings of Dhaka et al., (2003).

\section{Preferred sources of information}

Respondents were given a list of communication sources of gathering information regarding to livestock production and asked to select those they use often. Table 7 shows that, $85.20 \%$ (the highest percentage) of respondents rely on husband, friends and neighbors for acquisition of information. A significant number of respondent farm women rely on personal experience $(66.80 \%)$, opinion leaders $(46.80$ $\%)$, educated people $(41.20 \%)$, extension personnel $(34.80 \%)$ to seek information in respect of livestock production management. The above findings confirm findings of (Rezvanfar, 2007). The farm women depend on friends, husbands, neighbors and other native sources like local leaders and educated people for their information needs, while those sources of information are never to be reliable. So, farm women urgently need the formal system of information provision like the services of extension personal and veterinary/ animal husbandry officers to assist them with updated information in the subareas of sustainable livestock production in order to boost and sustain their productivity.

It may be concluded that women play a substantial role in livestock production management practices. They perform almost all the operations livestock production. But, they possessed poor knowledge regarding the ways of improving livestock productivity to improve livelihoods. It is highly recommended to giving adequate training and awareness to the farm women in the various aspects of good management practices for sustainable livestock production through different kinds of information and communication sources. The farm women depend on husbands, neighbors, friends and other native sources like local leaders and educated people for their information needs, while those sources of information are never to be reliable. So, women urgently need the formal system of information to assist them with updated information in the various aspects of livestock production in order to boost and sustain their productivity.

\section{References}

Center for Agricultural and Rural Cooperation. 1993. "A Woman's Rightful Place." Spore, No. 44: 1-4

Dhaka, B.L., Mann, J.S. and Solanki, V.K. 2003. Information need assessment of sheep rearers in semi-arid region of Rajasthan. Indian J. Small Ruminents, 10(2): 150-152.

Farinde, A.J. and Ajayi, A.O. 2005. Training needs of women farmers in livestock 
production: implications for rural development in Oyo state of Nigeria. $J$. Soc. Sci., 10(3): 159-164.

Misra, A.K. 2005. Contingency planning for feeding and management of livestock during drought. In: K D Sharma and K S Ramasastri (Eds) Drought Management. Allied Publishers Pvt. Ltd., New Delhi. Pp. 276-286

Rezvanfar, A., Moradnezhai, H. and Vahedi, M. 2007. Information needs of farm women related to dairy farming and home management in Ilam State of Iran Livestock Res. Rural Develop., Vol. 19. World Bank. 1992. Designing and implementing agricultural extension for women farmers. Technical Note. Washington DC: World Bank, Women and Development Division.

World Bank. 1999. India: Livestock Sector review: Enhancing growth and development. The World Bank and Allied Publishers: New Delhi.

\section{How to cite this article:}

Dhaka, B.L., R.K. Bairwa, N.L. Meena, G.S. Meena, K. Chayal and Nagar, B.L. 2017. Training Needs Assessment of Women Farmers on Livestock Production Management in Bundi District of Rajasthan, India. Int.J.Curr.Microbiol.App.Sci. 6(6): 796-803. doi: https://doi.org/10.20546/ijcmas.2017.606.093 